\title{
Responses of the splanchnic tissues of ruminants to changes in intake: absorption of digestion end products, tissue mass, metabolic activity and implications to whole animal energy metabolism *
}

\author{
I Ortigues ${ }^{1}, \mathrm{M}$ Doreau ${ }^{2}$ \\ 1 INRA, laboratoire croissance et métabolismes des herbivores; \\ 2 INRA-Theix, laboratoire sous-nutrition des ruminants, 63122 Saint-Genès-Champanelle, France
}

(Received 26 June 1994; accepted 7 January 1995)

\begin{abstract}
Summary - This review focuses on the influence of intake on the availability of digestion end products, on splanchnic tissue weights and metabolic activity, and on the consequences of these changes on whole animal energy metabolism in ruminants. An increase in intake reduces diet digestibility and modifies the relative importance of the sites of digestion. Passive absorption of volatile fatty acids depends on changes in blood flow with intake, whereas active absorption capacity of nutrients such as glucose does not seem to be greatly modified by intake. Consequently, with most diets, excluding the maize-based diets, the amount but not the balance of digestion end products is altered. Weights of the gastrointestinal tract and of the liver are subsequently increased with intake, due to the effects of both bulk and nutrient supply. Response time is very rapid and probably results from changes in tissue protein degradation rates and, to a lesser extent, from changes in tissue protein fractional synthesis rates. Metabolic rate of gut tissue is lower than that of liver but much higher than that of hind limbs. Intake may alter splanchnic tissue metabolic rates over a very short time period; however, no effects have been noted in the longer term. The combination of splanchnic tissue weight changes with intake and of high metabolic rates has important implications on whole animal energy metabolism. The increment in whole animal energy expenditure with intake originating from the portal drained viscera is $17-61 \%$; from the liver, $16-44 \%$; and from the carcass, $5-7 \%$.
\end{abstract}

splanchnic tissues / intake / absorption / tissue mass / energy metabolism

Résumé - Réponses des tissus splanchniques des ruminants à des changements de niveau d'alimentation : absorption de produits terminaux de la digestion, masse des tissus, activité métabolique et implications pour le métabolisme énergétique de l'animal entier. Cette revue traite de

\footnotetext{
* Report presented in the 9th Conference on Nutrition and Feeding of Herbivores, Clermont-
} Ferrand, France, 16-17 March 1994. 
l'influence du niveau d'alimentation sur la disponibilité en produits terminaux de la digestion, sur le poids et l'activité métabolique des tissus splanchniques et les conséquences de ces changements sur le métabolisme énergétique de l'animal entier chez les ruminants. Une augmentation du niveau d'alimentation diminue la digestibilité et modifie l'importance relative des sites de digestion. L'absorption passive des acides gras volatils dépend des variations de débits sanguins avec l'ingéré, alors que la capacité d'absorption active de nutriments tels que le glucose ne semble pas fortement modifiée par le niveau d'alimentation. Par conséquent, avec la majorité des régimes, à l'exception des régimes riches en maïs, seules les quantités mais non l'équilibre entre les produits terminaux de la digestion varient. Les poids de tube digestif et de foie sont accrus avec l'ingéré, suite à des effets de masse de contenus digestifs et d'apport de nutriments. Le temps de réponse est très rapide et semble provenir de modifications des taux de dégradation des protéines tissulaires et peut-être, dans une moindre mesure, des taux de synthèse protéique fractionnels. L'activité métabolique du tube digestif est inférieure à celle du foie, mais largement supérieure à celle du train-arrière. Le niveau d'alimentation modifie sans doute l'activité métabolique des tissus splanchniques à très court terme, mais aucune modification n'apparaît à long terme. La combinaison de changements de poids des tissus splanchniques avec lingéré et de taux métabolique élevé a des conséquences importantes sur le métabolisme énergétique de l'animal entier. L'augmentation de production de chaleur de l'animal entier avec le niveau d'alimentation provient pour 17 à $61 \%$ du tube digestif, pour 16 à $44 \%$ du foie et pour 5 à $7 \%$ de la carcasse.

tissu splanchnique / niveau d'alimentation / absorption / poids de tissus / métabolisme énergétique

\section{INTRODUCTION}

The digestive tract plays a key role in the utilization of food by animals as it is the intermediate between the digestive processes which degrade feeds into relatively simple molecules and the metabolic utilization of these nutrients by all the different body tissues. Through its absorptive functions and with its own metabolic processes, it regulates the exogenous nutrient supply to body tissues. In ruminants, whether at maintenance, growing or in lactation, digestive tissues do not represent a large proportion of body weight (up to $12 \%$ ); however, their metabolic activity is extremely high and they subsequently contribute greatly to the energy requirements of the animals, accounting for 16 to $29 \%$ of total energy expenditure (Ortigues, 1991).

The liver also plays a key role in the metabolism of the whole animal, as the centre for the intermediary metabolism. It represents a smaller proportion of body weight $(1-2 \%)$, but its contribution to whole animal energy expenditure is similar to that of the digestive tract (17-31\%) (Ortigues, 1991).
By comparison, energy expenditure of muscles (35-50\% body weight) represent only 8 to $16 \%$ of total energy expenditure of the whole animal, while adipose tissues and skin represent $10 \%$ and up to $18 \%$ each (in vivo data by Harris et al, 1989; Lobley, 1990 and Symonds and Lomax, 1990, as well as conclusions from a modelling exercise by Gill et al, 1989). Other estimates for the whole carcass, which includes muscles, adipose tissues, skin and bones, are slightly higher at $45-60 \%$ (Ortigues and Durand, 1995; Ortigues et al, 1995). Other tissues such as kidneys, heart, brain and lungs each account for smaller proportions of total $\mathrm{O}_{2}$ consumption $(6-7,5-11,5$ and $6-7 \%$, respectively, as measured or estimated by Summers et al, 1988; Gill et al, 1989 and Reynolds et al, 1991). Consequently, any changes in the energy metabolism of the digestive tract and, to a similar extent, of the liver which might take place with intake, diet and physiological state could largely determine the variations in efficiency of energy utilization by the whole animal.

The objective of this review is to describe the changes in the energy expenditure of 
the gut and liver with intake and the consequences of these changes on whole animal energy expenditure. The term intake is used here to imply a change in the total amounts of feed ingredients without any changes in diet composition. The influence of intake on the availability of the different digestion end products will first be examined in terms of digestibility and absorption. Nutrient supply influences both tissue growth and the intensity of tissue metabolic activity. These aspects will be reviewed. The consequences of intake on the energy requirements of gut tissues and liver will then be developed. Finally, the importance of splanchnic tissues in determining the changes in whole animal energy metabolism with intake is presented.

In this review, the responses of gut tissues and of liver in terms of energy metabolism are compared with those of other tissues, in particular muscles. This review is based mostly on in vivo results. In vitro data were used only when in vivo data were lacking.

\section{RELATIONSHIPS BETWEEN INTAKE, AMOUNT AND NATURE OF DIGESTION END PRODUCTS AND ABSORPTION}

The influence of intake on digestion and absorption of nutrients from the gut lumen is developed here. An attempt will be made to determine whether possible limitations to the absorption of nutrients are due to digestive processes or to the absorption capacity of digestive tissues.

\section{Digestive processes and production of nutrients}

Increasing intake without modifying diet composition generally decreases the overall digestibility and particularly the ruminal organic matter (OM) digestibility (see the review of Sutton, 1980). The relationship between intake and digestibility, obtained from experiments principally carried out above maintenance requirements, appears to be linear (Leaver et al, 1969; Alwash and Thomas, 1971). This effect is due mainly to a reduction in the retention time of particles in the rumen with increasing intake (Colucci et al, 1990). Microbial capacity of degradation does not vary to a large extent with intake, although the activity of enzymes involved in cellulolysis is higher when animals are underfed (Kabré et al, 1994). The influence of intake on microbial activity is probably minor when compared to that on retention time (Kabré et al, 1995). The effect of intake on digestibility is larger with concentrate- than with forage-rich diets (Colucci et al, 1989): the influence of retention time of particles in the rumen on digestibility is probably highest when retention time is short and limits degradation, as with concentrate diets. As intake does not greatly affect the microbial ecosystem, the molar proportions of ruminal volatile fatty acids (VFA) remain unchanged or exhibit a slight increase in propionate with increasing intake, with diets based on forages as well as on concentrates (Doreau and Rémond, 1982; Kabré et al, 1995).

The decrease in ruminal digestibility when intake increases is generally compensated for by an increase in small and large intestine digestion, whatever the diet (Doreau and Rémond, 1982; Merchen et al, 1986). This increase is partial and is not always observed (review of Galyean and Owens, 1991). Consequently, VFA produced in the rumen are partially replaced by glucose produced in the small intestine (especially with diets rich in cereals of low ruminal degradability) and by VFA produced in the large intestine. Although direct experimental evidence is lacking, it can be assumed that the proportion of VFA produced in the large intestine is increased at high intakes since carbohydrate digestion in the large intestine results in VFA production. In addition, the molar proportions 
between the main VFA produced in the large intestine are rather constant whatever the diet (Bergman, 1990) and similar to those observed in the rumen with forage-rich diets. Consequently, it can be postulated that intake does not modify to a large extent the proportions of total VFA produced.

Starch digestibility is high, whatever the intake. However, starch is the component of the diet which is the most able to modify the nature of the digestion end products, since it produces VFA in the rumen and glucose in the small intestine. Increasing intake above maintenance decreases the ruminal digestion of starch almost exclusively with sources of starch which are slowly degradable in the rumen, such as maize (review of Sutton, 1980; Doreau and Rémond, 1982). At intakes below maintenance, it is likely that starch ruminal digestion is not modified and remains very high; however, experimental evidence is lacking.

Starch digestion in the intestines is not complete, and amounts digested in the intestines are linearly related to amounts escaping the rumen. Different experimental data suggest that limitations of starch intestinal digestion at very high intakes may be due to limitations of enzymatic activity. In normal conditions of feeding, however, the increase in intake involves an increase in total alpha-amylase activity and perhaps disaccharidase activity (reviews of Nocek and Tamminga, 1991 and Harmon, 1992). These latter activities could, however, be the limiting factor of starch digestibility at high intakes.

Intestinal digestibility of nutrients other than starch seems to be independent of feed intake. Lipid intestinal digestibility appears to be unrelated to fatty acid flow in the duodenum (review of Doreau and Ferlay, 1994). Thus an increase in intake, even with diets rich in lipids, does not modify fatty acid digestibility. The increase in feed intake results in an increase in amino acid flow to the duodenum, due to a higher by-pass of dietary protein and to an increase in microbial protein synthesis (review of Clark et al, 1992), because of a faster rate of passage of feed residues and microbes out of the rumen. From an analysis of literature data, Clark et al (1992) showed that the increase in duodenal non-ammonia nitrogen flow is linear and of the same magnitude as the increase in intake. Only a few results relate intestinal nitrogen digestibility to nitrogen escaping the rumen. No experimental evidence has been obtained for a decrease in digestibility when intake increases (Tamminga, 1983; MacRae et al, 1985).

\section{Absorption across epithelia}

In this section, absorption is considered as the uptake of nutrients from the epithelia of the various sections of the gut, and not as the flow of nutrients entering the portal blood after metabolism by the gastrointestinal tract (GIT), which is generally called net absorption.

Studies on the effects of intake on absorption have been carried out mainly for VFA and glucose, the former being absorbed by passive diffusion according to a concentration gradient, the latter being absorbed by passive diffusion as well as by active transport systems. Both mechanisms respond to changes in intake (Karasov and Diamond, 1983).

Using various methods of isolated rumen or of isotopic dilutions, several authors have shown that absorption rate of VFA is linearly related to their ruminal concentration within physiological concentrations (up to $130 \mathrm{mM}$ ) (Hogan, 1961; Weigand et al, 1972; Thorlacius and Lodge, 1973; Oshio and Tahata, 1984; Peters et al, 1990, 1992). Only Dijkstra et al (1993) found, by the method of isolated rumen, some decrease in VFA absorbability when ruminal VFA concentration was increased. It can be concluded that in physiological conditions, the 
passive diffusion of VFA across the rumen wall is not limited by their concentration.

Even if the theoretical rate of absorption is not limiting, the increase in liquid outflow rate towards the omasum due to increasing feed intake may reduce VFA absorption in the rumen (Owens and Goetsch, 1986; Tamminga and Van Vuuren, 1988). It can be assumed that VFA will be absorbed postruminally, so that total VFA absorption will not be modified by food intake: it has been shown that VFA absorption in the omasum increases with VFA concentration (Dardillat, 1973). Moreover, abomasal capacity for VFA absorption is similar to that of the rumen (Williams et al, 1968). According to Myers et al (1967), the efficiency of VFA absorption in the large intestine decreases when VFA concentration increases. In the same way, some experiments suggest that when OM digestion or VFA production in the large intestine is high, VFA absorption is not complete (Ørskov et al, 1970; Argenzio et al, 1975). However, the amount of VFA which escape absorption cannot be calculated.

It has recently been shown that the ability of rumen epithelium to absorb a given amount of VFA is reduced when animals are underfed for 1 month (Perrier et al, 1994). This effect is probably very rapid since a 2-d fast has the same effect, as suggested by observations of Pfander and Phillipson (1953) and demonstrated by Gäbel et al (1993). The practical importance of this result is not demonstrated yet since underfed animals produce less VFA and the absorptive capacity of the rumen may not be limiting then.

The lower VFA absorption capacity at low intakes can be related to a lower blood flow in digestive tissues (Mailman, 1982). In ruminants, portal blood flow is known to vary with metabolizable energy intake (reviews by Huntington, 1990 and Ortigues, 1991). More specifically, an increase in ruminal concentrations of VFA and $\mathrm{CO}_{2}$ pres- sure enhanced arterial ruminal blood flow (Sellers et al, 1964; Dobson et al, 1971), even though recent data obtained by intragastric infusions modulated this conclusion (Gross et al, 1990). In nonruminants, systematic studies have been conducted which showed clearer effects. At intestinal level, micellar fatty acids and glucose, to a lesser extent, are vasodilators, whereas amino acids have little effect on intestinal blood flow. In addition, bile enhanced the glucoseinduced hyperemia and rendered fatty and amino acids vasoactive (Gallavan and Chou, 1985). Conversely, in in situ studies, an increase in blood flow increased nutrient absorption in ruminants (Murray et al, 1987; Kohn et al, 1993).

As far as glucose is concerned, the intestinal absorption capacity is very high: in sheep, up to $300 \mathrm{~g}$ of glucose can be infused in the abomasum daily without saturation of the absorptive capacity of the intestine (Ørskov et al, 1971). In addition, Kreikemeier et al (1991) showed, in the small intestine of steers, that glucose absorption capacity is higher than glucose production from starch. However, in the distal small intestine, the glucose absorption rate could be lower than the starch hydrolysis rate; indeed when large amounts of starch are given, free glucose is found in ileal digesta. Any limitations in glucose absorption in the distal small intestine, when glucose flow is very high, could be due either to the very rapid transit time or to limitations of absorption capacity.

Generally, however, the activity of transport systems is considered to be non-limiting for the absorbability of nutrients (Seal and Reynolds, 1993). Among the enzymes involved in the active transport systems, the $\mathrm{Na}^{+}, \mathrm{K}^{+}$-ATPase has been the most studied (McBride and Kelly, 1990). The in vitro activity of this enzyme in gut tissues has tended to be enhanced by an increase in intake even if statistical significance was not always reached (McBride and Milligan, 
1982, 1985; Rompala et al, 1987; Kelly and McBride, 1990). An increase in dietary bulk also increased $\mathrm{Na}^{+}, \mathrm{K}^{+}$-ATPase activity (Rompala et al, 1988).

All this different information indicates that a change in intake results mostly in quantitative changes in the production of digestion end products. Significant changes in the balance of nutrients absorbed may also occur, but in very specific situations such as with high maize diets. Since absorption seems to be directly related to the production of nutrients in most nutritional situations, similar changes will be noted in terms of absorbability of exogenous nutrients by the GIT. It should be remembered, however, that tissues of GIT have another source of nutrient supply through arterial blood.

\section{EFFECT OF FEEDING LEVEL ON GASTROINTESTINAL TRACT AND LIVER WEIGHTS}

An increased supply of nutrients to splanchnic tissues with intake alters the mass of total and individual tissues of the splanchnic bed through changes in hyperplasia, hypertrophia and, consequently, in tissue protein turnover. These aspects are discussed here.

\section{Influence of intake on total weights}

Several experiments have shown a positive effect of intake on the weight of the digestive tract, when differences in intake were applied at the same empty body weight (Murray et al, 1977; Butler-Hogg, 1984). From 6 experiments in which intake and the nutritive value of the diet before slaughter were recorded, Johnson et al (1990) found that total weights of GIT and liver increased by 52 to $79 \mathrm{~g}$ for the former, and by 23 to 39 $\mathrm{g}$ for the latter, when dietary metabolizable energy intake increased by $1 \mathrm{MJ}$, irrespective of species (ovine or bovine) and phys- iological state (growth or lactation). The effect of intake on GIT and liver has first been shown on growing lambs by Wallace (1948): the influence of different intake levels applied over a 50-d fattening period was highly significant and almost independent of the previous feeding level. It has been clearly shown in this experiment that an increase in the proportion of GIT in empty body weight can be reverted by a subsequent low intake. Weight of GIT can even decrease in the course of growth, when intake is low. Moreover, there is no carryover effect of previous nutrition on GIT weight; only a moderate carry-over effect can be noted on liver weight. This phenomenon has since been confirmed with different types of animals: ovines or bovines, growing or mature, both for the GIT and the liver (Schake and Riggs, 1972; Winter et al, 1976; Koong et al, 1982; Ferrell et al, 1986; Varga and Tyrrell, 1989; Taylor and Murray, 1991). All these results show that changes in GIT and liver weights are not proportional to changes in total body weight: when animals are first underfed and then refed, proportional loss or gain of splanchnic tissues is of higher magnitude than the proportional loss and gain of body weight (Kabbali et al, 1992).

The adaptation to a given intake occurs very rapidly. The most demonstrative result is that of Rompala and Hoagland (1987), who showed that intake in the $5 \mathrm{~d}$ just preceding slaughter has a higher influence on the weight of the digestive tract than previous intakes. Similarly, the adaptation of liver to changes in feed intake appears to be very rapid (Richmond et al, 1988). In growing animals, the effect of intake is proportional to the duration of a given plane of feeding: the weight of GIT and liver of lambs of the same age can be more than 2-fold higher when animals have been fed at high intake for 16 weeks than when they have been fed at low level for the same period. In adult animals, the length of application of a given intake could have a lesser influence on the 
weight of GIT (Hight and Barton, 1965), except in the case of a very long and very severe undernutrition (Butler-Hogg, 1984). The short-term adaptation of GIT had been suggested previously by an experiment of Fell et al (1972) on sheep in which variations in GIT weight closely followed those in feed intake throughout lactation. In several experiments, it is clear that variations with physiological state are due to variations of feed intake rather than to physiological state by itself or body condition (Cowan et al, 1979, 1980; Doreau et al, 1985). However, Butler-Hogg et al (1985) showed in cows that, for the same feed intake, weight of the intestine (but not of the rumen) tended to be higher in late pregnancy than in dry nonpregnant state.

The increase in feed intake of a diet of constant composition implies an increase in both energy and protein intake. These 2 factors can be involved in variations of GIT weight so that their respective effects must be disconnected. The dietary protein content of the diet, at similar dry matter (DM) intake, did not modify the weight of GIT in trials by Sykes and Field (1972) and Cowan et al (1981). In contrast, Drouillard et al (1991) showed that energy or protein restriction have the same effects on total GIT and liver weights.

The rapid adaptation of GIT and liver weight to variations of intake has some consequences on the interpretation of slaughter data. Indeed, when animals are slaughtered at different body weights, it is not possible to establish with accuracy allometric equations for GIT or liver weights if they have not been managed in similar nutritional conditions.

\section{Comparative effects on the different parts of the digestive tract and on the liver}

Table I summarizes the effects of intake on the weights of different portions of the diges- tive tract. The degree of variation in tissue weight is mainly related to the magnitude of differences in feed intake. Within each portion of GIT, however, no consistent response is observed. The relative increase in the weights of rumen, intestine and liver with intake does not seem to depend on the species, ovine or bovine, nor on the physiological state, growth or lactation.

The effect of feed intake on the weight of the digestive tract can be due either to a bulk effect of food or to the availability of nutrients, either of digestive or of endogenous origin. The first hypothesis was tested by Rompala et al (1988), who introduced $10 \%$ of inert bulk in the diet. Bulk caused a small increase in stomach $(+6 \%)$ and large intestine $(+13 \%)$ weight, but not in small intestine weight. Rompala et al (1990) confirmed this effect with polyethylene, but not with polyurethane of the same volume, suggesting a mechanical effect on the epithelium rather than a fill effect. This absence of fill effect is consistent with the low variations in total rumen contents when intake is modified, whereas DM rumen contents vary in the same way as intake (Grimaud and Doreau, 1995). Rompala et al (1990) observed that bulk caused an increase in $\mathrm{Na}^{+}, \mathrm{K}^{+}$-ATPase activity, which could enhance glucose absorption. Moreover, in experiments in which forage or concentrate diets were compared at similar digestible energy intake (Bailey, 1986; Johnson et al, 1987), rumen, intestines and liver weight did not vary: only omasum weight was higher when fibre content increased. Jones et al (1985), Gibb et al (1992) and Sun et al (1994) fed animals either with forage- or with concentrate-rich diets given ad libitum so that digestible energy intake was higher for concentrate-rich diets. For these latter diets, large intestine weight was not modified, rumen weight was increased in 1 of 3 trials, small intestine weight was increased in 2 of 3 trials and liver weight was increased in all 3 trials. Among the experiments sum- 


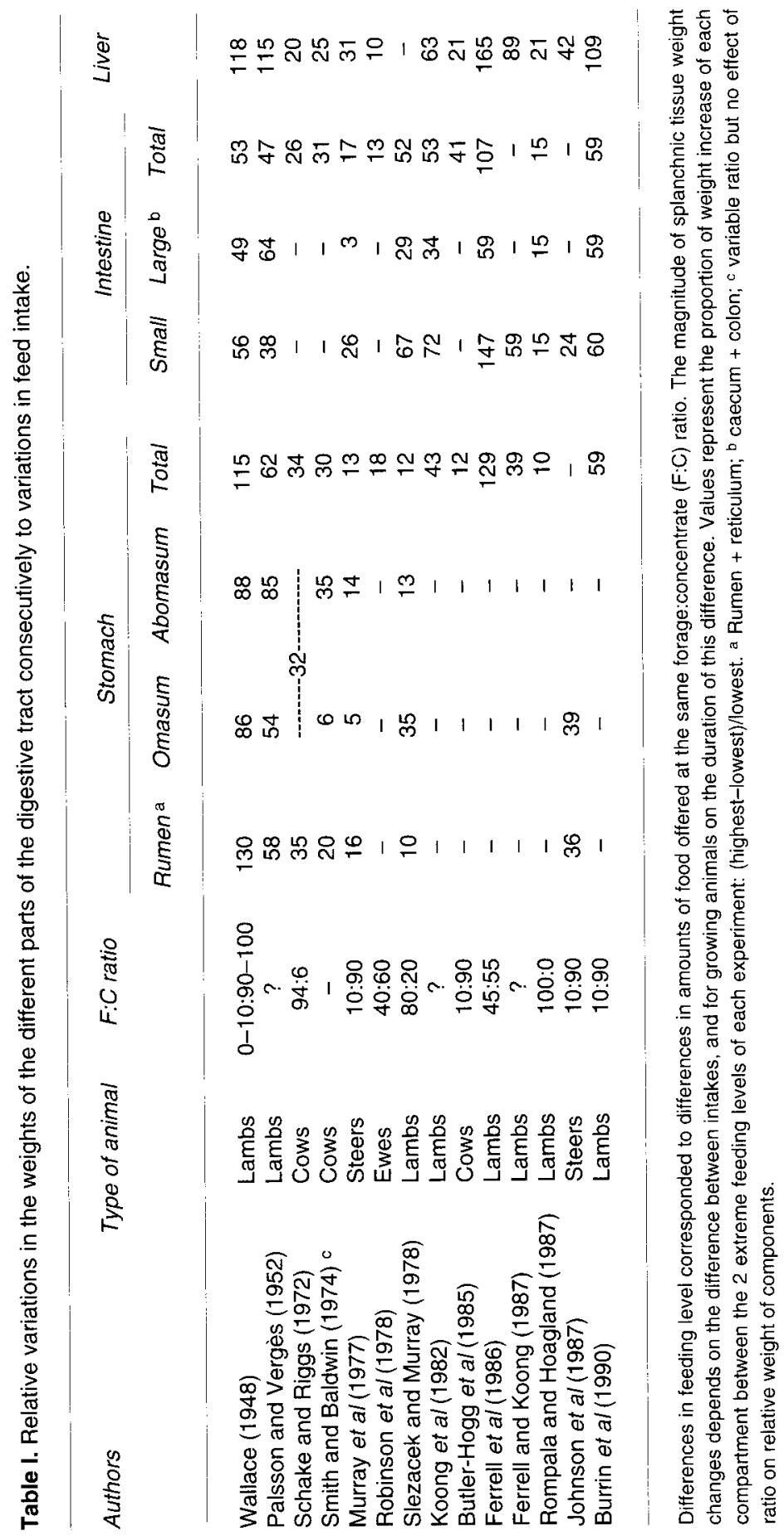


marized in table I in which the increase in small intestine weight was higher than that of the rumen, several were obtained with diets rich in concentrates (Koong et al, 1982; Butler-Hogg et al, 1985), but this trend was not general since it has also been observed with forage-based diets (Slezacek and Murray, 1978). In conclusion, liver weight seems to be related to the available nutrients. In addition, even though it is likely that bulk increases rumen weight, it is not clear from experimental data whether the amount of nutrients available influences only small intestine weight, as suggested by Drouillard et al (1991).

\section{Specific effects on epithelium and muscular layers of the digestive tract}

Weights of rumen or intestines are generally considered regardless of the histological and functional differences which exist between the epithelium and the muscular layers. The word epithelium or mucosa generally represents the sum of epithelial layers, basal lamina and connective tissues; the word muscular represents the 2 muscular layers and the serosa. The mass ratio between epithelium and muscular parts is about 40:60 for the rumen (Barnes et al, 1983); the effect of the proportion of dietary concentrate on this ratio has given contradictory results (Harrison et al, 1960; Stobo et al, 1966; Johnson et al, 1987). The effect of intake on the partition between epithelium and muscle has only been studied by Johnson et al (1987), who observed that increasing intake resulted in a similar increase in the epithelial and muscular parts of the rumen, whereas the higher weight of small intestine was only due to an increase in the weight of the epithelium, the weight of muscular layers remaining constant. The development of rumen muscular weight may be related to an increased strength required to mix rumen contents when the fill is higher; however, frequency of contractions is not modified to a large extent by intake (Ulyatt et al, 1984). The influence of intake on intestinal epithelium could be due to the increase in the amount of available nutrients arising from lumen or blood (see later).

In addition to the effect of intake on epithelial weight, morphology and histology of the epithelium could also be modified. Very few studies have focused on this aspect. In lambs, Drouillard et al (1991) did not observe any changes in the size of rumen papillae with feed restriction. On the contrary, there were morphological changes in intestinal mucosa consecutively to feed intake: height of villi was decreased when food intake was restricted (Rompala and Hoagland, 1987).

The increase in epithelial weight can be due either to an increase in area or in thickness. For the rumen as well as for the intestines, area seems to be increased.

Tulloh (1966) found a higher rumen water-filled volume, a higher length and circumference of the intestines in lactating than in dry cows. Palsson and Vergès (1952), Kreikemeier et al (1990) and Gibb et al (1992) also observed a positive relationship between intake and length of small intestine, for concentrate-rich as well as for forage-rich diets. However, the increase in length is not sufficient to explain variations in weight: an increase in thickness probably occurs. Such an observation has been made by Kreikemeier et al (1990) with a concentrate-rich diet but not with a foragerich diet.

\section{Variations in composition of digestive tract and liver}

In early lactation, females generally mobilize their body reserves to cover milk production when their intake capacity is limiting. Various authors (table II) have shown that 
between the 1st and the 5th to the 8th week of lactation, females lost carcass lipids and proteins; they also lost lipids in the GIT, but gained (especially when food intake was increased), or at least did not lose (when feed intake remained constant), proteins in the GIT. Similarly, Champredon et al (1990), comparing dry and early lactating goats, showed that lactation involved a gain in GIT proteins and a loss in GIT lipids. These experiments show that protein balance differs between GIT and the rest of the body. Protein weight gain in early lactation is more marked for rumen than for omasum, abomasum, small or large intestine (Cowan et al, 1980). It can be noted that, in these 2 experiments, total GIT weight did not vary, the decrease in lipids being compensated for by the increase in protein. In the trial of Gibb et al (1992), the effects of intake on liver protein weight was the same as for GIT, but liver protein weight did not vary in the trial of Cowan et al (1980), perhaps in relation with a moderate increase in DM intake.

Contrarily to these experiments, growing lambs submitted to a severe undernutrition lost high amounts of protein but no visceral lipids at all (Butler-Hogg, 1984; Drouillard et al, 1991). Moreover, in this lat- ter experiment, non-visceral and visceral protein varied in the same way consecutively to energy or protein restriction or refeeding. Loss of protein was shown with protein restriction but not with energy restriction.

This discrepancy between growing and lactating animals can be explained either by the fact that total viscera including internal fat was taken into account only in the 2 experiments on growing animals, or by the different hormonal patterns in growth and lactation. The common observation between all these experiments is that protein weight in GIT varies with DM and more probably with protein intake. Further experiments would be necessary for a better understanding of the regulation of accretion or loss of protein in the GIT.

\section{Components of tissue growth}

\section{Hyperplasia and hypertrophia}

The increase in GIT weight mentioned earlier can be obtained either by hyperplasia or by hypertrophia. It has clearly been shown that the presence of the 3 main VFA stimu-

Table II. Changes in protein and lipid weight of the carcass and of the gastrointestinal tract in early lactating females.

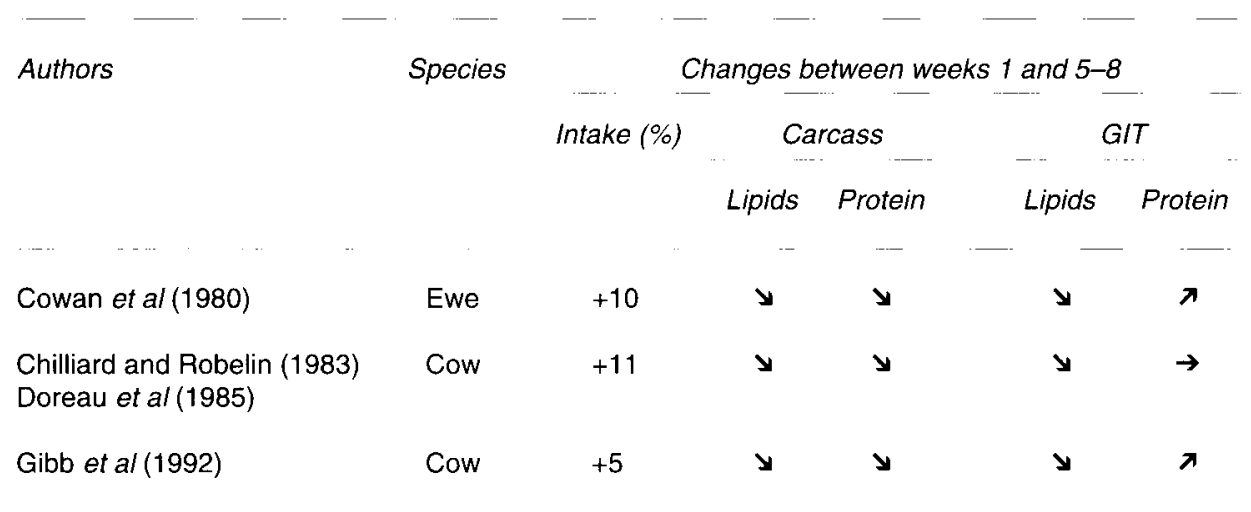


lates in vivo epithelial cell proliferation (estimated by the mitotic index) in adult ruminants at the ruminal (Sakata and Tamate, 1978, 1979) and intestinal (Sakata and Yajima, 1984) levels. It can be noted that the reverse effect is observed in vitro (Galfi et al, 1991), so that the effect observed in vivo is thought to be mediated by the influence of VFA on hormonal pattern. This effect is very rapid, 2 to $3 \mathrm{~d}$, and temporary, it lasts no more than 1 week. In vivo, the variations of mitotic index with feed intake are probably of a low magnitude, as shown by Moon and Campbell (1973), because level of intake only slightly modifies ruminal VFA concentrations.

Hyperplasia in an organ can be exhibited by the increase in DNA content in this organ. When intake increases, the concentration in DNA in the ruminal epithelium does not vary and DNA content increases (Moon and Campbell, 1973; Burrin et al, 1992). Ruminal growth could then be due to hyperplastic and probably to hypertrophic mechanisms. At the intestinal and liver levels, DNA content does not vary with intake (Burrin et al, 1992) so that growth is due to hypertrophia.

\section{Tissue protein turnover}

Tissue growth implies some changes in tissue protein metabolism. Among the components of tissue protein turnover, only synthesis rates have been studied so far in ruminants in relation with intake. Besides, only a limited number of reliable results have been obtained on in vivo protein synthesis in ruminant splanchnic tissues. These data are based on the use of the large dose technique (Attaix, 1988; Lobley et al, 1992).

In growing sheep, the in vivo fractional synthesis rates of the different component parts of the gut tended to increase with intake (Lobley et al, 1994). The majority of the responses, however, eluded statistical significance. These trends were not con- fined to the mucosa, which had the highest synthesis rates (in relation with the high turnover rate of villi cells), but were also generalized to the serosa (Lobley et al, 1994). The magnitude of response did not vary consistently with the type of tissue considered. In addition, even though the synthesis rate of secretory proteins was not directly measured, there were indications that this rate was enhanced in parallel to that of constitutive proteins (Pain et al, 1978; Lobley et al, 1994). This is important since $30 \%$ of the overall protein synthetic activity of the small intestinal mucosa of pigs was attributed to the secreted proteins (Reeds et al, 1993). Combining the previously mentioned results with those noted in terms of tissue mass raised the assumption that changes in gut mass with intake might be regulated through both protein degradation and protein synthesis (Attaix et al, 1992).

Similarly, the fractional synthesis rate of ovine liver proteins seemed insensitive to chronic alteration of intake (Lobley et al, 1994), altough small changes were observed by Lobley et al (1992) when less effective tracer flooding conditions were met. Since liver mass varied with intake, this again suggested that liver constitutive protein mass is primarily regulated by alterations in protein degradation. No direct evidence, however, is available in ruminants.

Other in vivo studies based on a continuous tracer infusion technique and dealing with the comparison of dry and lactating goats have shown similar non-significant trends (Champredon et al, 1990; Baracos et al, 1991). In these studies, the effect of intake was confounded with that of the physiological state. Nevertheless, the effect of intake might be predominant in the same way as intake appeared to be predominant in altering gut and liver tissue mass in lactating cows.

The lack of large effects of intake on the fractional protein synthesis rates in splanchnic tissues of sheep reported earlier are in 
agreement with the data obtained in 11-12 week old rats during phase I of starvation using a large dose technique (Attaix, 1988; Chérel et al, 1991). Indeed, the response to changing nutritional conditions depends on age (Lobley, 1993) as well as duration or severity of underfeeding. The most significant effects were noted for very young rats after a 2-d fast (McNurlan et al, 1979, 1982; Burrin et al, 1991). For older animals, a much longer fasting period was necessary for the fractional synthesis rates of both gut and hepatic tissues to be modified (Attaix, 1988; Chérel et al, 1991). This limited effect of intake on splanchnic protein synthesis rates is consistent with the observation that the precursor amino acid pool used for in vivo intestinal protein synthesis may be of plasmatic rather than of intraluminal (dietary) origin (Egan and Rennie, 1986, cited by Attaix, 1988). In addition and similarly to ruminants, indirect evidence has been obtained in rats that intestinal mass was partly regulated through changes in protein degradation rates (Attaix, 1988). For the liver, direct evidence exists in rats (Waterlow et al, 1978).

\section{TISSUE METABOLIC ACTIVITY}

Changes in splanchnic tissue mass subsequent to altered nutrient supply with intake may be accompanied by changes in tissue metabolic activity. The latter refers here to the general oxidative activity of tissues, measured as the quantity of $\mathrm{O}_{2}$ consumed per unit tissue weight and per unit time. The oxidative metabolism of tissues is known to sustain a variety of metabolic processes. In gut tissues, protein turnover and active transport systems could contribute in total for approximately $50 \%$ of the energy expenditure (Lobley, 1991). The other thermogenic components, such as smooth muscle tone and activity, substrate cycling, nucleic acid turnover, lipid synthesis, mitochondrial trans- port and so on (Summers et al, 1988; Lobley, 1991), have not yet been quantified in gut tissues. In the liver, Lobley (1991) estimated that tissue energy expenditure originated mainly from protein turnover $(12 \%)$, active transport systems (35\%), substrate cycles (24\%), gluconeogenesis $(20 \%)$ and urea synthesis $(15 \%)$.

Unfortunately, information on the effect of intake on in vivo gut and liver tissue metabolic activity is limited to that obtained in a study by Burrin et al $(1989,1990)$. Consequently, recently obtained knowledge on tissue metabolic activity is reviewed and indirect evidence for changes with feeding level is considered on the basis of blood flow through tissues.

\section{Metabolic rate}

An increasing number of published studies have now reported the in vivo mass specific metabolic rates of tissues (table III) based on in vivo measurements of tissue $\mathrm{O}_{2}$ consumption, followed by slaughter of the animals, and removal and weighing of the tissues. These data confirm that large differences exist between the portal drained viscera, the liver and other tissues such as the limbs. The in vivo metabolic rates were highest for the liver $\left(2.8-9.3 \mathrm{mmol} \mathrm{O}_{2}\right.$ consumed $/ \mathrm{d} / \mathrm{g}$ wet tissue), intermediate for the portal drained viscera (1.3-3.1 $\mathrm{mmol} \mathrm{O}_{2}$ consumed $/ \mathrm{d} / \mathrm{g}$ wet tissue) and lowest for the hind limbs $\left(0.22-0.43 \mathrm{mmol} \mathrm{O}_{2}\right.$ consumed/d/g wet tissue).

Published results are still too scarce to detect any systematic changes in tissue metabolic rate with the nutritional status of the animals. A few studies (Webster and White, 1973; Ortigues et al, 1995) suggested that over a 24-h period, metabolic rates of the portal drained viscera and of the liver increased postprandially probably in response to changes in specific nutrient supply (Ortigues et al, 1995) and in hor- 


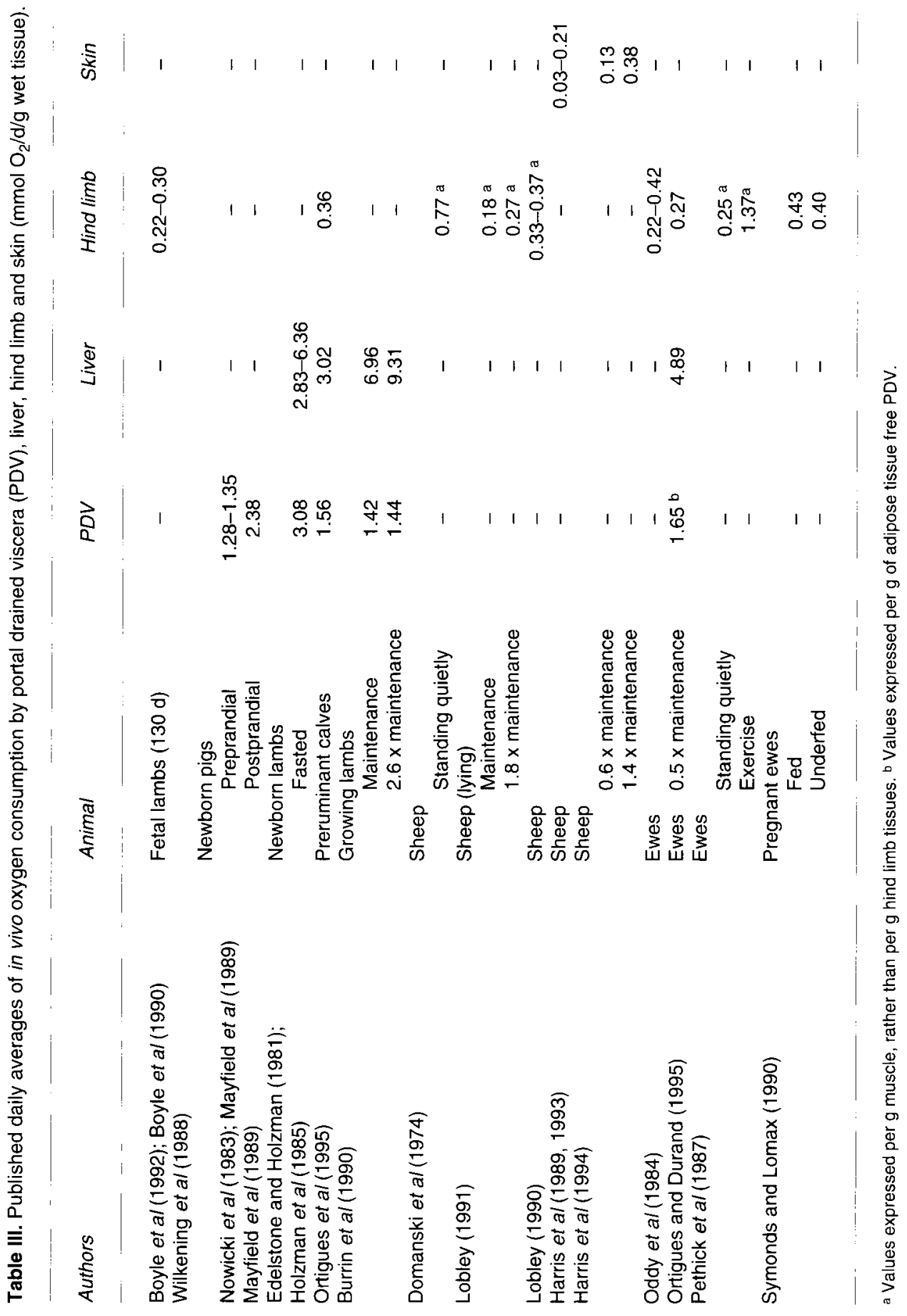


monal balance (Christopherson and Brockman, 1989). In the longer term, however, it is not certain that the mass specific metabolic activity of splanchnic tissues is modified. Burrin et al (1990) showed that after 3 weeks of adaptation, the in vivo metabolic rates of the portal drained viscera and of the liver were not significantly affected by intake, suggesting that the changes in total energy expenditure of these tissues arose only from changes in tissue weights. By contrast, intake appeared to modify the in vivo metabolic rate of the hind limbs (Harris et al, 1989).

In vitro data might have cast further light on these effects. However, in vitro metabolic rates of gut and liver tissues have not been clearly altered by intake (see Ortigues, 1991, for review). Additionally, some discrepancies exist between the published in vivo and in vitro metabolic rates, suggesting some caution in the interpretation of the in vitro data. The principal discrepancy pertained to the liver whose metabolic rate was 2 to 6 times higher in vivo than in vitro (Johnson et al, 1990; Ortigues, 1991). Concerning the portal drained viscera, it may be questioned whether the in vitro metabolic rate of the epithelium is also underestimated. Indeed, the epithelium is very active metabolically because of its absorptive function and its high turnover rate; nevertheless, its in vitro metabolic rate (Ortigues, 1991) was similar to the average in vivo metabolic rate of the whole portal drained viscera. Finally, higher metabolic rates were measured in vitro for muscle alone than in vivo for hind limb preparations, which generally include muscles, adipose tissues, bones and skin (Lobley, 1990).

\section{Relationships between energy expen- diture and blood flow}

It has been suggested that a close relationship exists between $\mathrm{O}_{2}$ consumption and blood flow through a tissue (Coulson, 1986). Lindsay (1993) found some correlation between total portal blood flow and total $\mathrm{O}_{2}$ consumption by the portal drained viscera of ruminants. Different correlations probably exist for each tissue. Indeed, blood flows are highly correlated with $\mathrm{O}_{2}$ flows to the tissues, whereas the $\mathrm{O}_{2}$ extraction capacity of tissues differs. For example, the portal drained viscera extract from 21 to $30 \%$ of the $\mathrm{O}_{2}$ flow; a similar extraction capacity has been noted for the liver $(17-36 \%)$, whereas much higher values are obtained in the hind-limbs (36-64\%) (Eisemann and Nienaber, 1990; Huntington et al, 1990; Symonds and Lomax, 1990; Reynolds et al, 1991, 1992; Ortigues and Durand, 1995).

In addition, the relationship between blood flow and oxygen consumption for each tissue may vary with the nutritional conditions. For example, in an experiment with adult ewes fed at 1 and 0.5 times the maintenance metabolizable energy (ME) requirements, the reduction in energy expenditure of splanchnic tissues with undernutrition was greater than the reduction in blood and $\mathrm{O}_{2}$ supply, leading to some decrease in the $\mathrm{O}_{2}$ extraction rates as a percent of supply (Ortigues and Durand, 1995). In contrast, the energy expenditure of the hindquarters was maintained constant due to an increase in $\mathrm{O}_{2}$ extraction rates which partly counterbalanced the drop in supply. Consequently, changes in $\mathrm{O}_{2}$ supply (and thus in blood flow) explained $40 \%$ (portal drained viscera) or $50 \%$ (liver, hindquarters) of the changes in $\mathrm{O}_{2}$ consumption of tissues with intake (Ortigues and Durand, 1995).

\section{Blood flow per unit tissue weight}

On the basis of the previously mentioned relationships between tissue energy expenditure and blood flow, changes in blood flow per unit tissue weight with intake were inves- 
tigated as possible and partial indicators of changes in tissue metabolic rates with intake. Only short-term responses could be examined from the available data.

First and similarly to metabolic rates, blood flow measured in conscious animals using dilution or ultrasonic techniques and expressed per unit tissue weight varies according to the specific tissue considered. In sheep, blood flow in the portal drained viscera is only 10 to $30 \%$ that of the liver, and 3 to 10 times higher than that of leg tissues (table IV). These proportions are similar to those noted in terms of metabolic rates between the 3 tissue beds.

More specific information on tissue differences is obtained from measurements using radioactive microspheres. For the portal drained viscera, the epithelium of the reticulorumen is 10 to 60 times more irri- gated than the smooth muscles (table V). Among the other gut tissues, other but smaller differences could be noted, in particular the slightly lower mass specific blood flow in the large than in the small intestine. The pancreas is highly irrigated, whereas mesenteric and omental adipose tissues present a much reduced blood flow.

By comparison, blood flow through individual tissues of the limbs ranged from 1.9 to $65.6 \mathrm{ml} / \mathrm{min} / 100 \mathrm{~g}$ wet tissue in skeletal muscle, from 2.2 to $47.2 \mathrm{ml} / \mathrm{min} / 100 \mathrm{~g}$ in adipose tissues, from 0.3 to $22.2 \mathrm{ml} / \mathrm{min} / 100$ $\mathrm{g}$ in skin, and averaged 3 and $5 \mathrm{ml} / \mathrm{min} / 100$ $\mathrm{g}$ in connective tissues and bones, respectively (Hales, 1973; Bell et al, 1976; Gregory and Christopherson, 1986; Gregory et al, 1986; Rhodes et al, 1991; Hales and Fawcett, 1993). These wide ranges show that very large differences exist among indi-

Table IV. Mass specific blood flow through portal drained viscera, liver and leg tissues $(\mathrm{ml} / \mathrm{min} / 100 \mathrm{~g}$ wet tissue) measured in conscious animals.

Authors

$-$

Burrin et al $(1989,1990)$

Ortigues and Durand (1995)

Ortigues and Durand (1995)

Ortigues et al (1995)

Burrin et al $(1989,1990)$

Ortigues and Durand (1995)

Ortigues et al (1995)

Harris et al (1992)

Oddy et al (1984)

Ortigues and Durand (1995)

Ortigues et al (1995)

Teleni et a/ (1986)

Domanski et al (1974)

Pethick et al (1987)

Pethick et al (1981)

Pethick and Vernau (1984)
Tissue

Animal

Portal drained viscera

Stomachs + intestine

Adipose tissue free

Total

Liver

$\begin{array}{lc}\text { Growing lambs } & 72-83 \\ \text { Ewes } & 109 \\ \text { Ewes } & 51 \\ \text { Preruminant calves } & 74\end{array}$

Growing lambs

Ewes

348-427

Preruminant calves

453

223

Leg

Whole

Growing lambs

Standing ewes

Standing ewes

Preruminant calves

Muscles

Sheep

Standing sheep

Sheep

Ewes

Ewes
2.6-9.1

$7.0-13.2$

5.8

9.6

7.4

24

7.2

24

14.2 
vidual muscles, as well as among the individual anatomical sites of adipose tissues and skin.

It should first be noted that diet composition and thus partition of digestion along the tract may influence the mass specific blood flows. For example, in sheep fed at similar metabolizable energy intakes ( 167

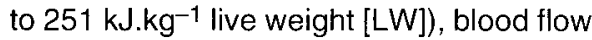
through tissues of the omasum down to the large intestine was much higher with concentrate-rich than with forage-rich diets. Unfortunately, no direct comparison could be obtained for the reticulorumen (table $\mathrm{V}$ ).
Within this context, short-term effects of intake on blood flow through specific tissues were measured but they seemed to vary with the type of diet considered. Blood flow through tissues appears to be relatively similar at zero intake regardless of previous diet (table V). However, with forage-rich diets, feeding increased blood flow mainly through the reticulorumen with little changes from the abomasum down to the large intestine (Barnes et al, 1983). With concentraterich diets, on the other hand, feeding also increased blood flow through the omasum, abomasum and small intestine even though

Table V. Mass specific blood flow ( $\mathrm{ml} / \mathrm{min} / 100 \mathrm{~g}$ wet tissue) through individual tissues of the portal drained viscera measured using microspheres in sheep.

Forage-based diet $\mathrm{a}, \mathrm{b}$

$2 \mathrm{~h}$ post-feeding $>18 \mathrm{~h}$ post-feeding
Concentrate-based diet $\mathrm{c}, \mathrm{d}$

$2 \mathrm{hpost-feeding} 18 \mathrm{hpost}$-feeding

Reticulorumen

Epithelium

Muscles

Overall

Omasum

Abomasum

Small intestine

Duodenum

Jejunum

lleum

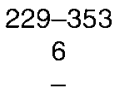

67

67

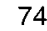

70

48

Large intestine

Caecum

Colon

51
32

59

31

Pancreas

335

381

93
74

72

57

98

$3-9$

-

-
-
$61-112$

$175-227$

147-204

115-128

$-$

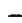

93-105

$288-340$

$223-290$

Adipose tissues Mesenteric Omental
3.6

2.0
6.5

6.0
4.6-10.7

9.3-23.1
6.1-14.9
9.4-32.5

\footnotetext{
a Engelhardt and Hales (1977); b Barnes et al (1986); ‘ Gregory and Christopherson (1986); d Gregory et al (1986). Intakes were estimated to range from 171 to $251 \mathrm{~kJ} \mathrm{ME} / \mathrm{kg}$ live weight (LW) in a, from 175 to $188 \mathrm{~kJ}$ $\mathrm{ME} / \mathrm{kg} \mathrm{LW}$ in ${ }^{\circ}$ and to an average of $176 \mathrm{~kJ} / \mathrm{kg} \mathrm{LW}$ in ${ }^{\circ}$ and $\mathrm{d}$.
} 
the rise was not as marked as in the forestomatchs (Gregory et al, 1986). A tendency also existed for reduced blood flow through adipose tissues with feeding (Barnes et al, 1983; Gregory and Christopherson, 1986).

Consequently, it can be concluded that the extent to which the portal drained viscera and the liver are sollicited for digestive and absorptive functions may potentially determine their average mass specific blood flow and/or metabolic activity in each nutritional condition. Concerning the specific effect of intake, the limited evidence did not suggest any definite modifications in the metabolic rates of splanchnic tissues after a few weeks of adaptation to the new intakes. This agrees with the observations that the rates of the 2 major components of energy expenditure in these tissues (ion transport and protein synthesis) were only slightly affected by intake. It could only be inferred from blood flow data that a few changes may occur in a very short time period after the change in feed allowances. Such a response would probably last only a few days until tissue weights have stabilized to a new level.

\section{INCREMENT OF TISSUE ENERGY EXPENDITURE WITH INTAKE}

From the previous discussion, it appears that because of the very high metabolic rate of splanchnic tissues by comparison with that of other tissues, the changes in tissue mass will have important consequences in terms of their total energy expenditure whether no or only short-lived modifications in metabolic rates are noted. It is thus of interest to quantify for each tissue the increase in energy expenditure with intake. Using results obtained in experiments where 2 different intakes were applied, the increase in tissue energy expenditure was calculated for each multiple of maintenance ME intake (taken at $481 \mathrm{~kJ} . \mathrm{kg} \mathrm{LW}-0.75 . \mathrm{d}^{-1}$ ). It ranged from 25 to $142 \mathrm{~kJ} . \mathrm{kg} \mathrm{LW}^{-0.75} . \mathrm{d}^{-1}$ for the portal drained viscera, and from 25 to $134 \mathrm{~kJ} . \mathrm{kg}$ $L W^{-0.75} \cdot \mathrm{d}^{-1}$ for the liver (table VI). The lowest values generally refer to high concentrate-rich diets, whereas the highest values were obtained with silages or grass hays. In addition, the increase in energy expenditure might be proportionally larger at high than at low intakes (Webster et al, 1975). In contrast, the increment in energy expenditure due to the total musculature measured at low intakes was extremely small. Higher increments would probably be obtained at higher intakes, but it is still likely that the discrepancy between muscle and splanchnic tissues would remain.

More generally, for the portal drained viscera, Seal and Reynolds (1993) estimated by regression using results from different published experiments that its energy expenditure increased by an average of $52 \mathrm{~kJ} . \mathrm{kg} \mathrm{LW}-0.75 . \mathrm{d}^{-1}$ for each multiple of maintenance ME intake. These authors also noted a tendency for the increment in energy expenditure by the portal drained viscera to be higher with silage than with dried forageor concentrate-rich diets. The lowest values had been obtained in experiments where animals were fed intragastrically. These differences probably reflect the changes in the work of digestion with the physical and chemical nature of the diet, gut fill as well as the nature of the components absorbed, since gut tissue mass was not clearly influenced by diet composition.

\section{CONTRIBUTION OF TISSUES \\ TO THE INCREASE IN WHOLE ANIMAL ENERGY EXPENDITURE WITH INTAKE}

The efficiency with which ME can support maintenance and production depends on the energy expenditure at different intakes. An increasing number of studies have shown that a large proportion of this incre- 


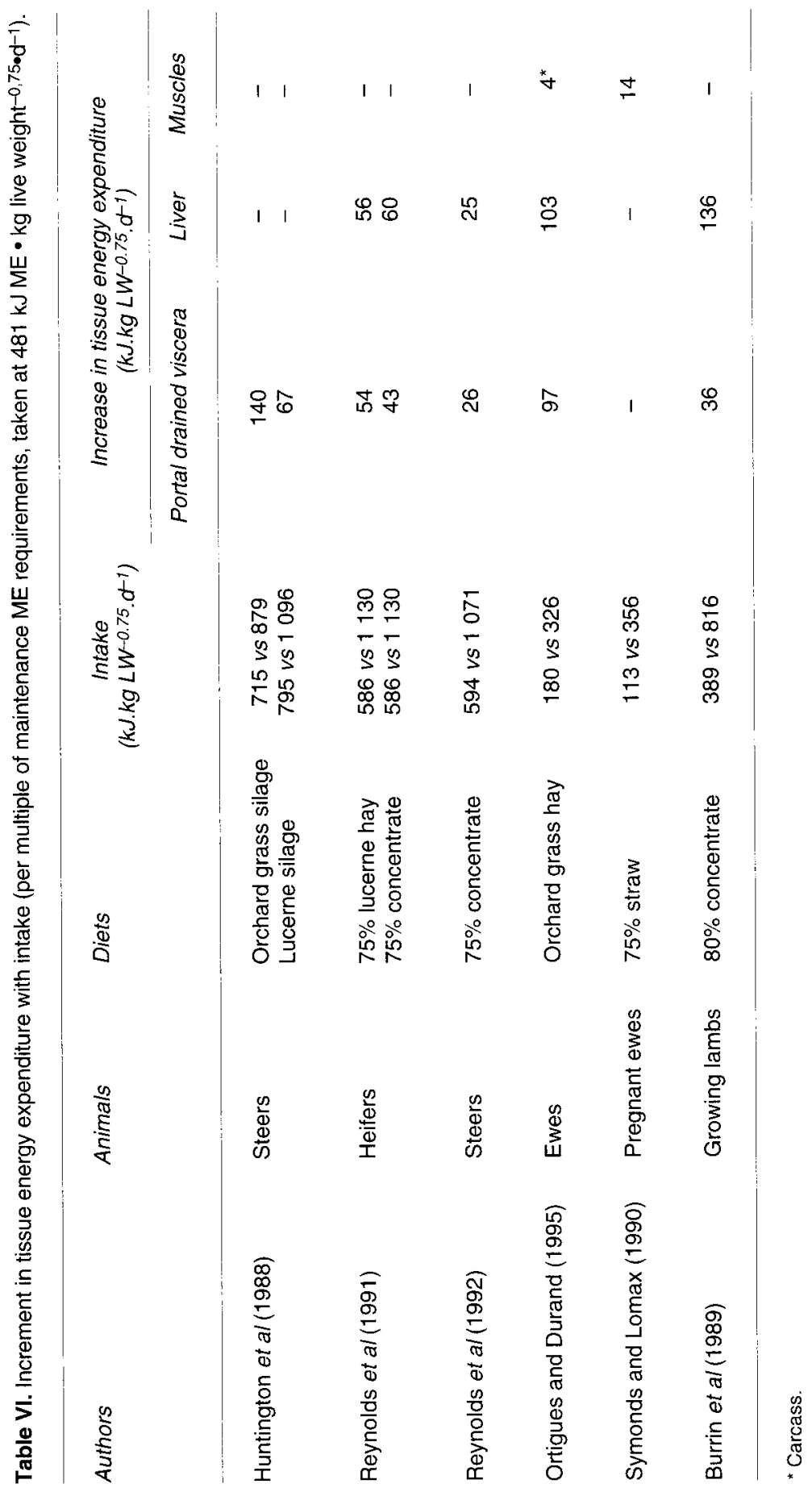


ment in energy expenditure was not directly associated with productive functions in tissues of economic importance (eg muscle deposition in growing animals), but rather with support functions by other tissues. The digestive tract, in particular, is the first to be challenged by modifications in the availability of digestion end products. From these studies, it may be assumed that its mass specific absorption activity and metabolic rate will be altered probably only transiently, but that changes in mass will occur very rapidly. Because of its high metabolic rate, the subsequent contribution of the portal drained viscera to the increase in total energy expenditure with increments of intake is quite important. It has been measured that 17 to $61 \%$ of the increase in whole animal energy expenditure with intake originated from the portal drained viscera (Webster et al, 1975; Huntington et al, 1988, 1990; Reynolds et al, 1991, 1992; Ortigues and Durand, 1995) (table VII). This contribution varied with the composition of the diet. The lowest contributions were generally obtained with concentrate-rich diets $(17-20 \%)$. Intermediate values were obtained when legumes (lucerne) were used as the main forage in forage-rich diets $(28-31 \%)$ and the highest contributions were obtained with grasses (39-46\%).

These contributions should be compared with those from other tissues (table VII). Changes in hepatic metabolism with intake will also contribute greatly to the increase in energy expenditure, by 14 to $44 \%$ (Huntington et al, 1990; Reynolds et al, 1991, 1992; Ortigues and Durand, 1995). Similarly to the portal drained viscera, the contribution of the liver in fed conditions seems to be more important with foragerich $(32-44 \%)$ than with concentrate-rich diets $(16-24 \%)$.

In contrast to the splanchnic tissues, the other components of the increment in energy expenditure are of much smaller magnitude. The skeletal muscles or the carcass con- tributed only 5 to $7 \%$ to the increase in whole animal energy expenditure with intake (table VII; Symonds and Lomax, 1990; Ortigues and Durand, 1995), which is disproportionately small considering the importance of these tissues in terms of weight. Eating also contributed up to $9 \%$ (Webster et al, 1975; Ortigues and Durand, 1995), whereas renal function did not seem to be greatly altered (Reynolds et al, 1991). As a consequence of the previously mentioned changes, contributions of splanchnic tissues to total energy expenditure of the whole animal increased with intake, whereas that of the carcass decreased (Ortigues, 1991; Ortigues and Durand, 1995).

\section{CONCLUSION}

A general understanding of the relationships between feed intake and digestion in the different compartments of the GIT, as well as between production of nutrients and their absorption, is obtained from a large number of experiments. However, it is not possible as yet to evaluate with accuracy the amount of nutrients absorbed by the GIT. Further research on digestion in the large intestine and on the stoichiometric relationships between ruminally degraded $O M$ and VFA production is necessary to improve knowledge in this area.

It has been shown that the rate of adaptation of GIT tissues to variations in intake is very rapid. Some aspects remain unclear, such as the influence of the nature of the diet on changes in GIT tissue weight: no effect is shown by experimental data, whereas the increase in energy expenditure of GIT with intake clearly varies with the forage:concentrate ratio. A better understanding of GIT metabolism should be gained from the knowledge of which nutritional factors determine proteolysis and proteosynthesis of the digestive tract, as well as the contribution of the different metabolic 


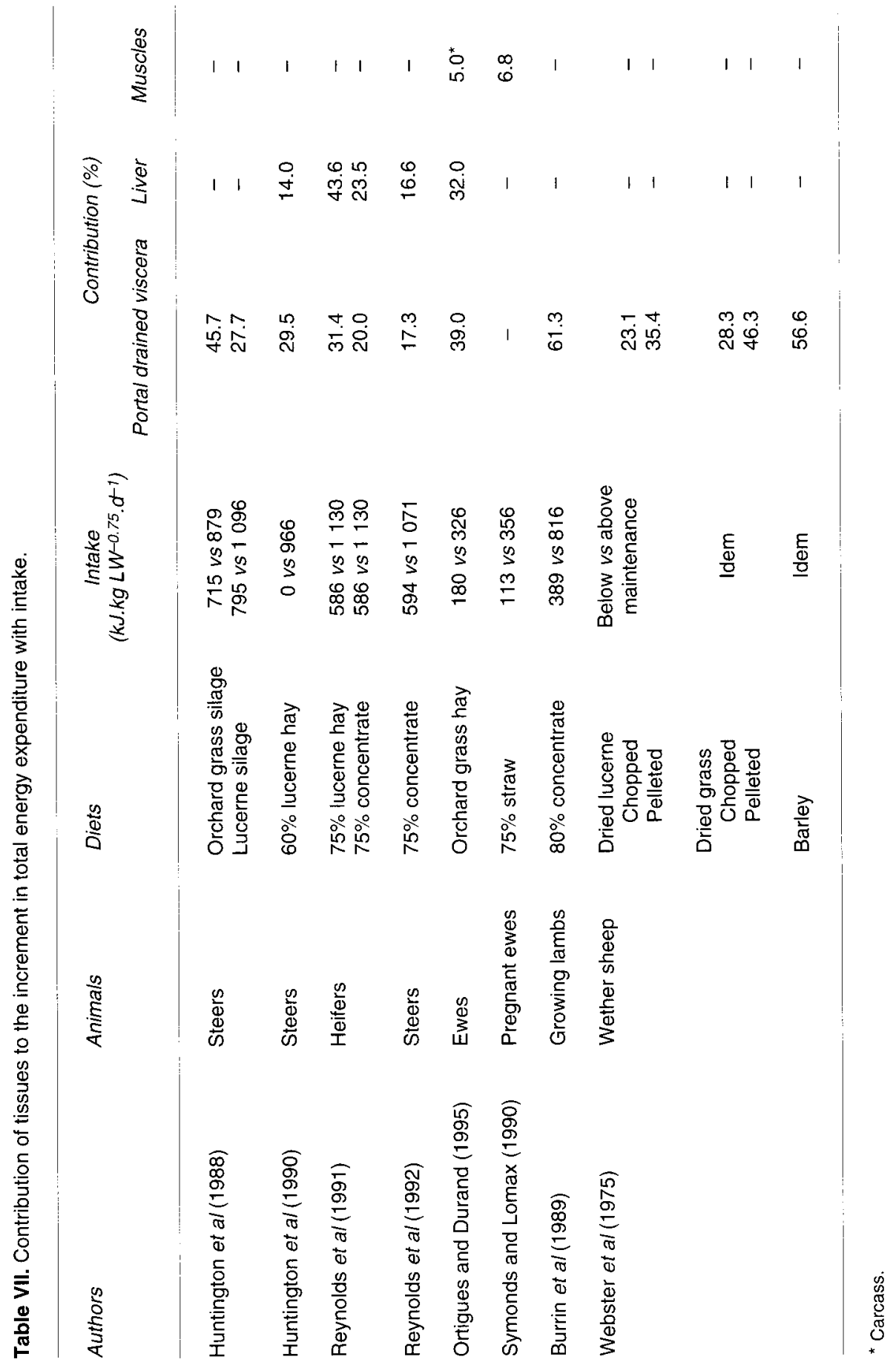


pathways to total energy expenditure of the GIT.

The figures stress the predominant role of the splanchnic tissue in determining the efficiency of energy utilization for maintenance and production. The energy expended at splanchnic levels will partly depend on the supply of exogenous nutrients to other tissues and thus their metabolic utilization. The development of in vivo studies on the relationship between energy expenditure and intake appears necessary, taking into account the possible difference of mechanisms involved when animals are either fed at high levels, as high-producing dairy cows, or at levels below maintenance.

\section{REFERENCES}

Alwash AH, Thomas PC (1971) The effect of the physical form of the diet and the level of feeding on the digestion of dried grass by sheep. J Sci Food Agric 22, 611-615

Argenzio RA, Miller N, Engelhardt W von (1975) Effect of volatile fatty acids on water and ion absorption from the goat colon. Am J Physiol 229, 997-1002

Attaix $D$ (1988) Influence de l'âge et du sevrage sur la synthèse protéique chez l'agneau. Thesis $n^{\circ} \mathrm{E} 416$ Univ Clermont-Ferrand II, France

Attaix D, Aurousseau E, Rosolowska-Huszcz D, Bayle G, Arnal M (1992) In vivo longitudinal variations in protein synthesis in developing ovine intestine. $A m J$ Physiol 263, R1318-R1323

Bailey CB (1986) Growth of digestive organs and their contents in holstein steers: relation to body weight and diet. Can J Anim Sci 66, 653-661

Baracos VE, Brun-Bellut J, Marie M (1991) Tissue protein synthesis in lactating and dry goats. Br J Nutr 66 , 451-465

Barnes RJ, Comline RS, Dobson A (1983) Changes in the blood flow to the digestive organs of sheep induced by feeding. Quart J Exp Physiol 68, 77-88

Barnes RJ, Comline RS, Dobson A (1986) The control of splanchnic blood flow. In: Control of digestion and metabolism in ruminants (LP Milligan, WL Grovum, A Dobson, eds), Prentice Hall, Englewood Cliffs, NJ, USA, $41-59$

Bell AW, Hilditch TE, Horton PW, Thompson GE (1976) The distribution of blood flow between individual muscles and non-muscular tissues in the hind limb of the young ox (Bos Taurus): values at thermoneu- trality and during exposure to cold. J Physiol 257 229-243

Bergman EN (1990) Energy contributions of volatile fatty acids from the gastrointestinal tract in various species. Physiol Rev 70, 567-590

Boyle DW, Hirst K, Zerbe GO, Meschia G, Wilkening RB (1990) Fetal hind limb oxygen consumption and blood flow during acute graded hypoxia. Pediatr Res $28,94-100$

Boyle DW, Meschia G, Wilkening RB (1992) Metabolic adaptation of fetal hind limb to severe, nonlethal hypoxia. Am J Physiol 263, R1130-R1135

Burrin DG, Ferrell CL, Eisemann JH, Britton RA, Nienaber JA (1989) Effect of level of nutrition on splanchnic blood flow and oxygen consumption in sheep Br J Nutr 62, 23-34

Burrin DG, Ferrell CL, Britton RA, Bauer M (1990) Level of nutrition and visceral organ size and metabolic activity in sheep. Br J Nutr 64, 439-448

Burrin DG, Davis TA, Fiorotto ML, Reeds PJ (1991) Stage of development and fasting affect protein synthetic activity in the gastrointestinal tissues of suckling rats. J Nutr 121, 1099-1108

Burrin DG, Britton RA, Ferrell CL, Bauer ML (1992) Level of nutrition and visceral organ protein synthetic capacity and nucleic acid content in sheep. J Anim Sci 70, 1137-1145

Butler-Hogg BW (1984) Growth patterns in sheep: changes in the chemical composition of the empty body and its constituent parts during weight loss and compensatory growth. J Agric Sci (Camb) 103, 17-24

Butler-Hogg BW, Wood JD, Bines JA (1985) Fat partitioning in British Friesian cows: the influence of physiological state on dissected body composition. J Agric Sci (Camb) 104, 519-528

Champredon C, Debras E, Patureau-Mirand P. Arnal M (1990) Methionine flux and tissue protein synthesis in lactating and dry goats. J Nutr 120, 1006-1015

Chérel Y, Attaix D, Rosolowska-Huszcz D, Belkhou R, Robin JP, Arnal M, Le Maho $Y$ (1991) Whole-body and tissue protein synthesis during brief and prolonged fasting in the rat. Clin Sci 81, 611-619

Chilliard $Y$, Robelin $J$ (1983) Mobilization of body proteins by early lactating cows measured by slaughter and $\mathrm{D}_{2} \mathrm{O}$ dilution techniques. In: Protein metabolism and nutrition, Publ 31, Vol II, EAAP, INRA Publications, 195-198

Christopherson RJ, Brockman RP (1989) Effect of feeding and a $\beta$-adrenergic blocking agent on oxygen consumption by the portal drained viscera, liver and hindquarters of the sheep. In: Energy metabolism of farm animals ( $Y$ van der Honing, WH Close, eds), Pudoc, Wageningen, 147-150

Clark JH, Klusmeyer TH, Cameron MR (1992) Microbial protein synthesis and flows of nitrogen fractions to the duodenum of dairy cows. J Dairy Sci 75, 23042323 
Colucci PE, MacLeod GK, Grovum WL, Cahill LW, McMillan I (1989) Comparative digestion in sheep and cattle fed different forage to concentrate ratios at high and low intakes. J Dairy Sci 72, 1774-1785

Colucci PE, MacLeod GK, Grovum WL, McMillan I, Barney DJ (1990) Digesta kinetics in sheep and cattle fed diets with different forage to concentrate ratios at high and low intakes. J Dairy Sci 73, 2143-2156

Coulson (1986) Metabolic rate and the flow theory: a study in chemical engineering. Comp Biochem Physiol 84A, 217-229

Cowan RT, Robinson JJ, Greenhalgh JF, McHattie I (1979) Body composition changes in lactating ewes estimated by serial slaughter and deuterium dilution. Anim Prod 29, 81-90

Cowan RT, Robinson JJ, McDonald I, Smart R (1980) Effects of body fatness at lambing and diet in lactation on body tissue loss, feed intake and milk yield of ewes in early lactation. J Agric Sci (Camb) 95, 497514

Cowan RT, Robinson JJ, McHattie I, Pennie K (1981) Effects of protein concentration in the diet on milk yield, change in body composition and the efficiency of utilization of body tissue for milk production in ewes. Anim Prod 33, 111-120

Dardillat C (1973) Absorption des acides gras volatils dans l'omasum de la vache. Ann Biol Anim Biochim Biophys 13, 793-795

Dijkstra J, Boer H, Van Bruchem J, Bruining M, Tamminga $S$ (1993) Absorption of volatile fatty acids from the rumen of lactating dairy cows as influenced by volatile fatty acid concentration, $\mathrm{pH}$ and rumen liquid volume. Br J Nutr 69, 385-396

Dobson A, Sellers AF, Thorlacius SO (1971) Limitation of diffusion by blood flow through bovine ruminal epithelium. Am J Physiol 220, 1337-1343

Domanski A, Lindsay DB, Setchell BP (1974) Blood flow and substrate uptake and oxidation in the hind limb muscles of sheep. J Physiol 242, 28P-29P

Doreau M, Rémond B (1982) Comportement alimentaire et utilisation digestive d'une ration de composition constante chez la vache laitière en fin de gestation et début de lactation. Reprod Nutr Dev 22 , 307-324

Doreau M, Ferlay A (1994) Digestion and utilization of fatty acids by ruminants. Anim Feed Sci Technol 45, 379-396

Doreau M, Robelin J, Lestrade A (1985) Effects of physiological state and body fatness on digestive-tract weight and composition in the dairy cow. Livest Prod Sci $12,379-385$

Drouillard JS, Klopfenstein TJ, Britton RA, Bauer ML, Gramlich SM, Wester TJ, Ferrell CL (1991) Growth, body composition, and visceral organ mass and metabolism in lambs during and after metabolizable protein or net energy restrictions. J Anim Sci 69 , $3357-3375$
Edelstone DI, Holzman IR (1981) Gastrointestinal tract $\mathrm{O}_{2}$ uptake and regional bood flows during digestion in conscious newborn lambs. Am J Physiol 241, G289-G293

Eisemann $\mathrm{JH}$, Nienaber JA (1990) Tissue and wholebody oxygen uptake in fed and fasted steers. $\mathrm{Br} J$ Nutr 64, 399-411

Engelhardt W von, Hales JRS (1977) Partition of capillary blood flow in rumen, reticulum, and omasum of sheep. Am J Physiol 232, E53-E56

Fell BF, Campbell RM, Mackie WS, Weekes TEC (1972) Changes associated with pregnancy and lactation in some extra-reproductive organs of the ewe. J Agric Sci (Camb) 79, 397-407

Ferrell CL, Koong LJ (1987) Response of body organs of lambs to differing nutritional treatments. In: Energy metabolism of farm animals (PW Moe, HF Tyrrell, PJ Reynolds, eds), Rowman and Littlefield, Totowa, USA, 26-29

Ferrell CL, Koong LJ, Nienaber JA (1986) Effect of previous nutrition on body composition and maintenance energy costs of growing lambs. Br J Nutr 56, 595-605

Gäbel G, Marek M, Martens H (1993) Influence of food deprivation on SCFA and electrolyte transport across sheep reticulorumen. $J$ Vet Med Assoc 40, 339-344

Galfi P, Neogrady S, Sakata T (1991) Effects of volatile fatty acids on the epithelial cell proliferation of the digestive tract and its hormonal mediation. In: Physiological aspects of digestion and metabolism in ruminants (T Tsuda, Y Sasaki, R Kawashima, eds), Academic Press, San Diego, CA, USA, 49-59

Gallavan RH, Chou CC (1985) Possible mechanisms for the initiation and maintenance of postprandial intestinal hyperemia. Am J Physiol 249, G301-G308

Galyean ML, Owens FN (1991) Effects of diet composition and level of feed intake on site and extent of digestion in ruminants. In: Physiological aspects of digestion and metabolism in ruminants ( $T$ Tsuda, $Y$ Sasaki, R Kawashima, eds), Academic Press, San Diego, CA, USA, 483-514

Gibb MJ, Ivings WE, Dhanoa MS, Sutton JD (1992) Changes in body components of autumn-calving Holstein-Friesian cows over the first 29 weeks of lactation. Anim Prod 55, 339-360

Gill M, France J, Summers M, McBride B, Milligan LP (1989) Simulation of the energy costs associated with protein turnover and $\mathrm{Na}^{+}, \mathrm{K}^{+}$transport in growing lambs. J Nutr 119, 1287-1299

Gregory NG, Christopherson RJ (1986) Effect of fasting on capillary blood flow in sheep. Res Vet Sci 40 , 357-360

Gregory NG, Christopherson RJ, Lister D (1986) Adipose tissue capillary blood flow in relation to fatness in sheep. Res Vet Sci 40, 352-356

Grimaud P, Doreau M (1995) Effect of extended underfeeding on digestion and nitrogen balance in nonlactating cows. J Anim Sci 73, 211-219 
Gross KL, Harmon DL, Avery TB (1990) Portal drained visceral flux of nutrients in lambs fed alfalfa or maintained by total intragastric infusion. J Anim Sci 68 , 214-221

Hales JRS (1973) Radioactive microsphere measurement of cardiac output and regional tissue blood flow in the sheep. Pflügers Arch 344, 119-132

Hales JRS, Fawcett AA (1993) Wool production and blood supply to skin and other tissues in sheep. J Anim Sci 71, 492-498

Harmon DL (1992) Dietary influences on carbohydrases and small intestinal starch hydrolysis capacity in ruminants. J Nutr 122, 203-210

Harris PM, Garlick PJ, Lobley GE (1989) Interactions between energy and protein metabolism in the whole body and hind limb of sheep in response to intake. In: Energy metabolism of farm animals ( $Y$ van der Honing, WH Close, eds), Pudoc, Wageningen, 167170

Harris PM, Skene PA, Buchan V, Milne E, Galder AG, Anderson SE, Connell A, Lobley GE (1992) Effect of food intake on hind-limb and whole body protein metabolism in young growing sheep: chronic studies based on arterio venous techniques. Br J Nutr 68, 389-407

Harris PM, Lee J, Gurnsey MP, Dellow DW, Sinclair BR (1993) Measurement of blood flow and metabolite uptake by the skin of fleece weight-selected and control Romney rams. Austr J Agric Res 14, 255264

Harris PM, Lee J, Sinclair BR, Treloar BP, Gurnsey MP (1994) Effect of food intake on energy and protein metabolism in the skin of Romney sheep. Br J Nutr $71,647-660$

Harrison HN, Warner RG, Sander EG, Loos JK (1960) Changes in the tissue and volume of the stomachs of calves following the removal of dry feed or consumption of inert bulk. J Dairy Sci 43, 1301-1312

Hight GK, Barton RA (1965) The effects of undernutrition and re-alimentation on the Romney ewe. J Agric SCi (Camb) 64, 413-424

Hogan JP (1961) The absorption of ammonia through the rumen of the sheep. Austr J Biol Sci 14, 448-460

Holzman IR, Tabata B, Edelstone DI (1985) Effects of varying hematocrit on intestinal oxygen uptake in neonatal lambs. Am J Physio/ 248, G432-G436

Huntington GB (1990) Energy metabolism in the digestive tract and liver of cattle: influence of physiological state and nutrition. Reprod Nutr Dov 30, 35-47

Huntington GB, Varga GA, Glenn BP, Waldo DR (1988) Net absorption and oxygen consumption by Holstein steers fed alfalfa or orchard grass silage at 2 equalized intakes. J Anim Sci 66, 1292-1302

Huntington GB, Eisemann JH, Whitt JM (1990) Portal blood flow in beef steers: comparison of techniques and relation to hepatic blood flow, cardiac output and oxygen uptake. J Anim Sci 68, 1666-1673
Johnson CL, Johnson DE, Rumpler WV (1987) Source and level of alimentation effects on visceral organ mass of fat steers. In: Energy metabolism of farm animals (PW Moe, HF Tyrrell, PJ Reynolds, eds), Rowman and Littlefiled, Totowa, USA, 50-53

Johnson DE, Johnson KA, Baldwin RL (1990) Changes in liver and gastrointestinal tract energy demands in response to physiological workload in ruminants. J Nutr 120, 649-655

Jones SDM, Rompala RE, Jeremiah LE (1985) Growth and composition of the empty body in steers of different maturity types fed concentrate or forage diets. $J$ Anim Sci $60,427-433$

Kabbali A, Johnson WL, Johnson DW, Goodrich RD, Allen CE (1992) Effects of undernutrition and refeeding on weights of body parts and chemical components of growing Moroccan lambs. J Anim Sci 70, 2859-2865

Kabré P, Martin C, Michalet-Doreau B (1994) Enzyme activities of rumen solid adherent microorganisms in chronically underted ewes. J Sci Food Agric 65 , 423-428

Kabré P, Doreau M, Michalet-Doreau B (1995) Effects of underfeeding and of fish meal supplementation on forage digestion in sheep. J Agric Sci (Camb) 124 , 119-127

Karasov WH, Diamond JM (1983) Adaptive regulation of sugar and amino acid transport by vertebrate intestine. Am J Physiol 245, G443-G462

Kelly JM, McBride BW (1990) The sodium pump and other mechanisms of thermogenesis in selected tissues. Proc Nutr Soc 49, 185-202

Kohn RA, Schwab CG, Bozak CK, Hyiton WE (1993) Effect of intestinal blood flow on absorptive site blood flow and lysine absorption as examined in situ in Holstein calves. J Anim Sci 71, 1641-1647

Koong LJ, Ferrell CL, Nienaber JA (1982) Effects of plane of nutrition on organ size and fasting heat production in swine and sheep. In: Energy metabolism in farm animals (A Ekern, F Sundstøl, eds), Agric Univ of Norway, Lillehammer, Norway, 245-248

Kreikemeier KK, Harmon DL, Peters JP, Gross KL, Armendariz CK, Krehbiel CR (1990) Influence of dietary forage and feed intake on carbohydrase activities and small intestinal morphology of calves. $J$ Anim Sci68, 2916-2929

Kreikemeier KK, Harmon DL, Brandt RT Jr, Avery TB, Johnson DE (1991) Small intestinal starch digestion in steers: effect of various levels of abomasal glucose, corn starch and corn dextrin infusion on small intestinal disappearance and net glucose absorption. J Anim Sci 69, 328-338

Leaver JD, Campling RC, Holmes W (1969) The effect of level of feeding on the digestibility of diets for sheep and cattle. Anim Prod 11, 11-18

Lindsay DB (1993) Metabolism of the portal-drained viscera. In: Quantitative aspects of ruminant digestion 
and metabolism (JM Forbes, J France, eds), CAB International, Wallingford, UK, 267-289

Lobley GE (1990) Energy metabolism reactions in ruminant muscle: responses to age, nutrition and hormonal status. Reprod Nutr Dev 30, 13-34

Lobley GE (1991) Organ and tissue metabolism: present status and future trends. In: Energy metabolism of farm animals (C Wenk, M Boessinger, eds), Institut für Nutztierwissenschaften, Zürich, Switzerland, 80-87

Lobley GE (1993) Species comparisons of tissue protein metabolism: effects of age and hormonal action. J Nutr 123, 337-343

Lobley GE, Harris PM, Skene PA, Brown D, Milne E Calder AG, Anderson SE, Garlick PJ, Nevison I, Connell A (1992) Responses in tissue protein synthesis to sub- and supra-maintenance intake in young growing sheep: comparison of large-dose and continuous-infusion techniques. Br J Nutr 68, 373-388

Lobley GE, Connell A, Milne E, Newman AM, Ewing TA (1994) Protein synthesis in splanchnic tissues of sheep offered 2 levels of intake. Br J Nutr 71, 3-12

MacRae JC, Smith JS, Dewey PJS, Brewer AC, Brown DS, Walker A (1985) The efficiency of utilization of metabolizable energy and apparent absorption of amino acids in sheep given spring- and autumn-harvested dried grass. Br J Nutr 54, 197-209

McBride BW, Milligan LP (1982) Energy expenditure associated with $\mathrm{Na}^{+}$and $\mathrm{K}^{+}$transport in intestinal epithelium of sheep and cattle. Can J Anim Sci 62, 1263

McBride BW, Milligan LP (1985) Influence of feed intake and starvation on the magnitude of $\mathrm{Na}^{+}, \mathrm{K}^{+}$-ATPase (EC 3.6.1.3)-dependent respiration in duodenal mucosa of sheep. Br J Nutr 53, 605-614

McBride BW, Kelly JM (1990) Energy cost of absorption and metabolism in the ruminant gastrointestinal tract and liver: a review. J Anim Sci 68, 2997-3010

McNurlan MA, Tomkins AM, Garlick PJ (1979) The effect of starvation on the rate of protein synthesis in rat liver and small intestine. Biochem J 178, 373-379

McNurlan MA, Fern EB, Garlick PJ (1982) Failure of leucine to stimulate protein synthesis in vivo. Biochem J 204, 831-838

Mailman D (1982) Blood flow and intestinal absorption. Fed Proc 41, 2096-2100

Mayfield SR, On W, Piva DL, Stonestreet BS (1989) Postprandial gastrointestinal blood flow and oxygen consumption during environmental cold stress. Am J Physiol 256, G364-G368

Merchen NR, Firkins JL, Berger LL (1986) Effect of intake and forage level on ruminal turnover rates, bacterial protein synthesis and duodenal amino-acid flows in sheep. J Anim Sci 62, 216-225

Moon SJ, Campbell RM (1973) Effects of reproduction in sheep on the rate of cell division and nucleic acid content of the ruminal mucosa. J Agric Sci (Camb) $80,443-449$

Murray DM, Tulloh NM, Winter WH (1977) The effect of 3 different growth rates on some offal components of cattle. J Agric Sci (Camb) 89, 119-128

Murray RA, Nocek JE, Schwab CG, Hylton WE, Bozak CK (1987) Description and validation of an in situ autoperfusion method to determine nutrient absorption and metabolism in bovine small intestine. J Anim Sci $65,841-860$

Myers LL, Jackson HD, Packett LV (1967) Absorption of volatile fatty acids from the cecum of sheep. $J$ Anim Sci $26,1450-1458$

Nocek JA, Tamminga S (1991) Site of digestion of starch in the gastrointestinal tract of dairy cows and its effect on milk yield and composition. J Dairy Sci 74 . 3598-3629

Nowicki PT, Stonestreet BS, Hansen NB, Yao AC, Oh W (1983) Gastrointestinal blood flow and oxygen consumption in awake newborn piglets: effect of feeding. Am J Physiol 245, G697-G702

Oddy VH, Gooden JM, Annison EF (1984) Partitioning of nutrients in Merino ewes. I. Contribution of skeletal muscle, the pregnant uterus and the lactating mammary gland to total energy expenditure. Austr J Biol Sci 37, 375-388

Orskov ER, Fraser C, Mason VC, Mann SO (1970) influence of starch digestion in the large intestine of sheep on caecal fermentation, caecal microfiora and faecal nitrogen excretion. Br J Nutr 24, 671-682

Ørskov ER, Mayes RW, Penn A (1971) The capacity for the removal of glucose from the small intestine by mature sheep. Proc Nutr Soc 30, 43A-44A

Ortigues I (1991) Adaptation du métabolisme énergétique des ruminants à la sous-alimentation. Quantification au niveau de l'animal entier et de tissus corporels. Reprod Nutr Dev 31, 593-616

Ortigues I, Durand D (1995) Adaptation of energy metabolism to undernutrition in ewes. Contribution of portal-drained viscera, liver and hindquarters. $\mathrm{Br} \mathrm{J}$ Nutr 73, 209-226

Ortigues I, Martin C, Durand D. Vermorel M (1995) Circadian changes in energy expenditure in the preruminant calf: whole animal and tissue level. $J$ Anim Sci $73,552-564$

Oshio S, Tahata I (1984) Absorption of dissociated volatile fatty acids through the rumen wall of sheep. Can J Anim Sci 64 (Suppl), 167-168

Owens FN, Goetsch AL (1986) Digesta passage and microbial protein synthesis. In: Control of digestion and metabolism in ruminants (LP Milligan, WL Grovum, A Dobson, eds), Prentice-Hall, Englewood Cliffs, NJ, USA, 196-223

Pain VM, Garlick PJ, McNurlan MA (1978) Synthesis of albumin and of total plasma proteins by liver of fed and starved rats. Proc Nutr Soc 37, 29A 
Palsson H, Vergès JB (1952) Effect of the plane of nutrition on growth and the development of carcass quality in lambs. J Agric Sci (Camb) 42, 1-92; 93-149

Perrier R, Ferchal E, Durier C, Doreau M (1994) Effect of undernutrition on the ability of the sheep rumen to absorb volatile fatty acids. Reprod Nutr Dev 34, 341 347

Peters JP, Shen RYW, Robinson JA, Chester ST (1990) Disappearance and passage of propionic acid from the rumen of the beef steer. J Anim Sci 68, 3337 3349

Peters JP, Shen RYW, Robinson JA (1992) Disappearance of acetic acid from the bovine reticulorumen at basal and elevated concentrations of acetic acid. $J$ Anim Sci 70, 1509-1517

Pethick DW, Vernau B (1984) The effect of acetate on the utilization of glucose by skeletal muscle on the sheep hindlimb. Can J Anim Sci 64 (Suppl 1), 291292

Pethick DW, Lindsay DB, Barker PJ, Northrop AJ (1981) Acetate supply and utilization by the tissues of sheep in vivo. Br J Nutr 46, 97-110

Pethick DW, Harman N, Chong JK (1987) Non-esterified long-chain fatty acid metabolism in fed sheep at rest and during exercise. Austr J Biol Sci 40, 221 234

Pfander WH, Phillipson AT (1953) The rates of absorption of acetic, propionic and n-butyric acids. J Physiol 122, 102-110

Reeds PJ, Burrin DG, Davis TA, Fiorotto ML (1993) Postnatal growth of gut and muscle: competitors or collaborators. Proc Nutr Soc 52, 57-67

Reynolds CK, Tyrrell HF, Reynolds PJ (1991) Effects of diet forage-to-concentrate ratio and intake on energy metabolism in growing beef heifers: whole body energy and nitrogen balance and visceral heat production. I Nutr 121, 994-1003

Reynolds CK, Lapierre H, Tyrrell HF, Elsasser TH, Staples RC, Gaudreau P, Brazeau P (1992) Effects of growth hormone-releasing factor and feed intake on energy metabolism in growing beef steers: net nutrient metabolism by portal-drained viscera and liver. $J$ Anim Sci 70, 752-763

Rhodes MT, Paterson JA, Kerley MS, Garner HE, Laughlin $\mathrm{MH}$ (1991) Reduced blood flow to peripheral and core body tissues in sheep and cattle induced by endophyte-infected tall fescue. J Anim Sci69, 20332043

Richmond CE, Lunt DK, Greene LW, Byers FM (1988) Effects of dietary restriction and subsequent re-alimentation on liver mass in growing/finishing beef steers. Nutr Rep Intern 38, 501-507

Robinson JJ, McDonald I, McHattie I, Pennie K (1978) Studies on reproduction in prolific ewes. 4 . Sequential changes in the maternal body during pregnancy. J Agric Sci (Camb) 91, 291-304
Rompala RE, Hoagland TA (1987) Effect of level of alimentation on visceral organ mass and the morphology and $\mathrm{Na}^{+}, \mathrm{K}^{+}$adenosinetriphosphatase activity of intestinal mucosa in lambs. J Anim Sci 65, 10581063

Rompala RE, Johnson DE, Rumpler WV, Phetteplace HW, Parker CF (1987) Level of alimentation and line of breeding on oxygen uptake by ovine jejunal mucosa. Am J Physiol 252, R398-R401

Rompala RE, Hoagland TA, Meister JA (1988) Effect of dietary bulk on organ mass, fasting heat production and metabolism of the small and large intestines in sheep. J Nutr 118, 1553-1557

Rompala RE, Hoagland TA, Meister JA (1990) Modifications in growth and morphology of ovine jejunal and ruminal epithelia as affected by inert dietary substances. J Anim Sci 68, 2530-2535

Sakata T, Tamate H (1978) Rumen epithelial cell proliferation accelerated by rapid increase in intraruminal butyrate. J Dairy Sci61, 1109-1113

Sakata T, Tamate H (1979) Rumen epithelium cell proliferation accelerated by propionate and acetate. $J$ Dairy Sci 62, 49-52

Sakata T, Yajima T (1984) Influence of short chain fatty acids on the epithelial cell division of digestive tract. Quart J Exp Physiol 69, 639-648

Schake LM. Riggs JK (1972) Body weight changes of mature beef cows. J Anim Sci 34, 491-496

Seal CJ, Reynolds CK (1993) Nutritional implications of gastrointestinal and liver metabolism in ruminants. Nutr Res Rev6, 185-208

Sellers AF, Stevens CE, Dobson A, McLeod FD (1964) Arterial blood flow to the ruminant stomach. $A m J$ Physiol 207, 371-377

Slezacek O, Murray DM (1978) Growth rate effects on the alimentary tract and associated fat of sheep. Proc Austr Soc Anim Prod 12, 238

Smith NE, Baldwin RL (1974) Effects of breed, pregnancy and lactation on weight of organs and tissues in dairy cattle. J Dairy Sci 57, 1055-1060

Stobo IJF, Roy JHB, Gaston HJ (1966) Rumen development in the calf. 1 . The effect of diets containing different proportions of concentrates to hay on rumen development. Br J Nutr 20, 171-188

Summers M, McBride BW, Milligan LP (1988) Components of basal energy expenditure. In: Aspects of digestive physiology in ruminants (A Dobson, $\mathrm{MJ}$ Dobson, eds), Cornell University Press, Ithaca, NY, USA, 257-282

Sun W, Goetsch AL, Forster LA Jr, Galloway DL Sr, Lewis PK Jr (1994) Forage and splanchnic tissue mass in growing lambs: effects of dietary forage levels and source on splanchnic tissue mass in growing lambs. Br J Nutr 71, 141-151

Sutton JD (1980) Digestion and end-product formation in the rumen from production rations. In. Digestive 
physiology and metabolism in ruminants ( $Y$ Ruckebusch, $P$ Thivend, eds), Clermont-Ferrand, 271-290

Sykes AR, Field AC (1972) Effects of dietary deficiencies of energy, protein and calcium on the pregnant ewe. I. Body composition and mineral content of the ewes. J Agric Sci (Camb) 78, 109-117

Symonds ME, Lornax MA (1990) Effect of chronic cold exposure and underfeeding on hind-limb tissue metabolism in pregnant sheep. J Agric Sci (Camb) $115,421-428$

Tamminga S (1983) Recent advances in our knowledge on protein digestion and absorption in ruminants. In: Protein metabolism and nutrition, Vol 1, INRA Publications, 263-287

Tamminga S, Van Vuuren AM (1988) Formation and utilization of end products of lignocellulose degradation in ruminants. Anim Feed Sci Technol 21, 141159

Taylor CS, Murray JI (1991) Effect of feeding level, breed and milking potential on body tissues and organs of mature, non-lactating cows. Anim Prod $53,27-38$

Teleni E, Annison EF, Lindsay DB (1986) Metabolism of valine and the exchange of amino acids across the hind-limb muscles of fed and starved sheep. Austr J Biol Sci 39, 379-393

Thorlacius SO, Lodge GA (1973) Absorption of steamvolatile fatty acids from the rumen of the cow as influenced by diet, buffers, and pH. Can J Anim Sci 53, 279-288

Tulloh NM (1966) Physical studies of the alimentary tract of grazing cattle. IV. Dimensions of the tract in lactating and non-lactating cows. NZJ Agric Res 9, 999-1008

Ulyatt MJ, Waghorn GC, John A, Reid CSW, Monro J (1984) Effect of intake and feeding frequency on feeding behaviour and quantitative aspects of digestion in sheep fed chaffed lucerne hay. J Agric Scl (Camb) 102, 645-657

Varga GA, Tyrrell HF (1989) Effect of prior rate of gain and end weight on energy metabolism, visceral organ mass and body composition of Angus $x$ Hereford steers. In: Energy metabolism of farm animals ( $Y$ Van der Honing. WH Close, eds), Pudoc, Wageningen, 287-290

Wallace LR (1948) The growth of lambs before and after birth in relation to the level of nutrition. $J$ Agric SCl (Camb) 38, 367-401

Waterlow JC, Garlick PJ, Millward DJ (1978) Protein turnover in mammalian tissues and in the whole body. North-Holland Publishing Co, Amsterdam

Webster AJF, White F (1973) Portal blood flow and heat production in the digestive tract of sheep. Br J Nutr $29,279-293$

Webster AJF, Osuji PO, White F, Ingram JF (1975) The influence of food intake on portal blood flow and heat production in the digestive tract of sheep. Br J Nutr 34, 125-139

Weigand E, Young JW, McGilliard AD (1972) Extent of butyrate metabolism by bovine ruminoreticulum epithelium and the relationship to absorption rate. $J$ Dairy Sci 55, 589-597

Wilkening RB, Molina RD, Meschia G (1988) Placental oxygen transport in sheep with different hemoglobin types. Am J Physio/ 254, R585-R589

Williams VJ, Hutchings TR, Archer KA (1968) Absorption of volatile fatty acids from the reticulo-rumen and abomasum of sheep. Aust J Biol Sci 21, 89-96

Winter WH, Tulloh NM, Murray DM (1976) The effect of compensatory growth in sheep on empty body weight, carcass weight and the weights of some offals. J Agric Sci (Camb) 87, 433-441 